\title{
Some Characteristics of Nisin Z, a Peptide Antibiotic Produced by Lactococcus lactis IO-1
}

\author{
Hiromi Matsusaki, Kenji SonOMOTO and Ayaaki IshizaKI \\ Laboratory of Microbial Technology, Department of Food Science and Technology, Faculty of Agriculture, Kyushu University, 6-10-1, \\ Hakozaki, Higashi-ku, Fukuoka 812-8581, Japan
}

Received March 13, 1998; Accepted June 24, 1998

Lactococcus lactis IO-1 isolated in our laboratory produces a peptide antibiotic, a natural nisin variant, nisin $\mathrm{Z}$. Nisin $\mathrm{Z}$ was heat stable at acidic $\mathbf{p H}$ and showed a bactericidal mode of action against an indicator strain, Bacillus subtilis $\mathrm{C}$. The effect of proteolytic enzyme treatment on the activity and the antimicrobial spectrum were tested. These results indicated nearly the same characteristics as those of nisin A. In this study, it was found that two nisin variants (nisin $Z$ and nisin $A$ ) were practically inactivated by proteinase $K$ and actinase $E$. Interestingly, nisin-producing strains, L. lactis IO-1 and L. lactis NCDO 497 (a nisin A producer) were sensitive to a high concentration of nisin variants including their own products. The growth of a Gram-negative bacterium, Escherichia coli, was also inhibited by a high concentration of nisin, although nisin producers and Gram-negative bacteria are generally resistant to nisin variants.

Keywords: nisin, bacteriocin, lantibiotic, lactic acid bacteria, Lactococcus

Historically, food fermentations were empirical and fortuitous processes based on the activities of the natural flora contaminating the raw material. Not only lactic acid bacteria are responsible for the specific taste and texture that develop during the preparation by fermentation of various kinds of traditional foods, but also they have prevented the rapid spoilage of dairy, meat and vegetables for a long time. Bacteriocins, proteinaceous compounds, produced by some lactic acid bacteria generally inhibit the growth of closely related species (Klaenhammer, 1988, 1993; Nettles \& Barefoot, 1993; Ralph et al., 1995). In these years, microbiological, biochemical and genetic characterization of bacteriocins have been well studied. Similarly, the possibility of whether novel bacteriocins isolated could be used as food preservatives should also be investigated. Nisin, or more precisely nisin A, the most famous bacteriocin, is heat-stable at acidic $\mathrm{pH}$ and has a broad antimicrobial spectrum against Gram-positive bacteria (Hurst, 1981); it has been accepted for use as a food preservative in many countries (Delves-Broughton, 1990). Because nisin $\mathrm{A}$ is unstable and inactivated at neutral $\mathrm{pH}$, however, its use as a preservative is limited at present. Nisin has two natural variants, nisin A (Gross \& Morell, 1971) and nisin Z (Mulders et al, 1991). Nisin Z is replaced histidine in nisin A with asparagine at position 27 (Fig. 1).

L. lactis IO-1 isolated in our laboratory produces a peptide antibiotic, which was purified and identified to be nisin $\mathrm{Z}$ (Matsusaki et al., 1996a). We also investigated the relationship between the primary metabolite production of nisin $\mathrm{Z}$ and lactate and cell growth, which had so far not been clarified in detail. This study resulted in a 3-fold activity of nisin $\mathrm{Z}$ in the culture broth under optimal conditions (Matsusaki et al. 1996b). Nisin Z has the possibility of use as a food preservative similarly to nisin A. Because there are only a few reports on the characterization and properties of nisin Z (De Vuyst \& Vandamme, 1994), however, we describe here in detail some characteristics of nisin $\mathrm{Z}$ purified from strain IO-1. Protein engineering and molecular design would enable the improvement of the stability and antimicrobial activity of nisin $\mathrm{Z}$ as a food preservative. Therefore, it is necessary that the characterization of $\mathrm{pH}$ and heat stability, sensitivity to proteolytic enzymes and antimicrobial spectrum of wild-type nisin $\mathrm{Z}$ is well investigated. The characterization and the properties of nisin $\mathrm{Z}$ elucidated in this study will also provide much information for the commercial application and effective production of nisin $\mathrm{Z}$.

\section{Materials and Methods}

Bacterial strains and culture conditions Lactococcus lactis IO-1 isolated in our laboratory was used as the nisin Z-producing strain (Matsusaki et al., 1996a). To compare nisin Z with nisin A, L. lactis NCDO 497, a nisin Aproducing strain, was also used. The indicator strain used for the assay of antimicrobial activity was Bacillus subtilis $\mathrm{Cl}$ as described previously (Matsusaki et al., 1996a). To test the sensitivity to nisin variants, $L$. lactis $\mathrm{JCM} 5805^{\mathrm{T}}$ (a nisin non-producer), L. lactis subsp. cremoris TUA 1344L, Enterococcus faecalis JCM 5803 ${ }^{\mathrm{T}}$, Clostridium acetobutylicum IFO $13948^{\mathrm{T}}$, B. subtilis $\mathrm{C1}$, B. subtilis JCM $1465^{\mathrm{T}}, B$. coagulans JCM $2257^{\mathrm{T}}$, B. stearothermophilus $\mathrm{JCM} 2501^{\mathrm{T}}$, Micrococcus luteus IFO12708 and Escherichia coli JM109 were used. All lactic acid bacteria, bacilli and $C$. acetobutylicum were grown as described previously (Matsusaki et al., 1996a). M. luteus and E. coli were grown on LB medium consisting of $1 \%$ bactotryptone, $0.5 \%$ yeast extract and $0.5 \%$ $\mathrm{NaCl}\left(\mathrm{pH} \mathrm{7.0)}\right.$ at $30^{\circ} \mathrm{C}$ and $37^{\circ} \mathrm{C}$, respectively.

Assay of antimicrobial activity For assay of the 


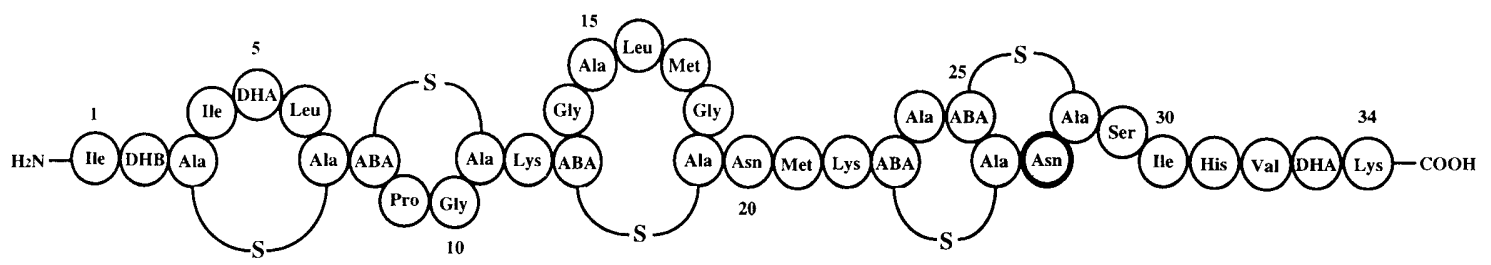

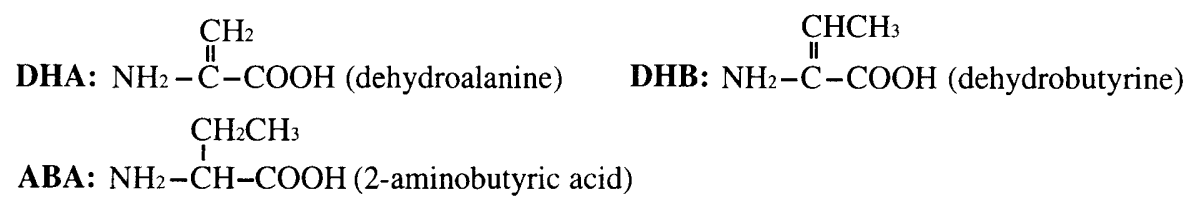

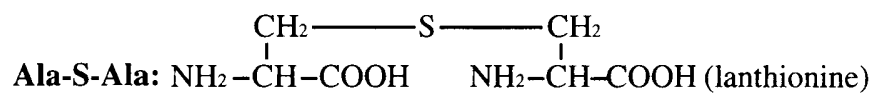

ABA-S-Ala: $\mathrm{NH}_{2}-\stackrel{\mathrm{C}}{\mathrm{C}} \mathrm{H}-\mathrm{COOH} \quad \stackrel{\mathrm{S}}{\mathrm{NH}_{2}-\stackrel{!}{\mathrm{C}} \mathrm{H}-\mathrm{COOH}(3-\text { methyllanthionine) }}$

Fig. 1. Structure of nisin Z. The structure of nisin Z was determined by Mulders et al. (1991). The amino acid residue at position 27 is histidine in nisin A (Gross \& Morell, 1971).

antimicrobial activity, the growth inhibition of the indicator strain, B. subtilis $\mathrm{Cl}$, was determined by turbidimetry as described previously (Matsusaki et al, 1996a). The assay medium consisted of $0.05 \%$ yeast extract (Difco, Detroit, Mich.), $0.05 \%$ polypeptone (Nihon Seiyaku, Co., Ltd., Tokyo), $0.05 \% \mathrm{NaCl}, 0.1 \%$ glucose and $20 \mathrm{~mm}$ sodium phosphate buffer ( $\mathrm{pH} 7.0)$. The activity unit of nisin variants produced by $\mathrm{IO}-1$ and NCDO 497 strains was defined as an arbitrary unit (AU) equivalent to the activity of $1 \mu \mathrm{g}$ of commercial nisin (nisin A; ICN Biomedicals, Inc., Costa Mesa, Cal.; activity, 1,000 U/mg-solid; nisin content, $2.5 \%$ ). Determination of activity was performed in duplicate or more each time.

Nisin preparation Nisin $\mathrm{Z}$ was recovered from the culture supernatant of $L$. lactis $\mathrm{IO}-1$ and was partially purified by acid treatment, ammonium sulfate precipitation and cation-exchange chromatography as described previously (Matsusaki et al., 1996a). The active fraction obtained from cation-exchange chromatography was used to characterize nisin Z. If necessary, the fraction was further purified through the steps of desalting and concentration with a $\mathrm{tC}_{18}$ Sep-Pak cartridge (Waters, Milford, Mass.) and lyophilization (Matsusaki et al., 1996a). Nisin A was also purified from the culture supernatant of strain NCDO 497 in a manner similar to the above.

Effect of heat treatment and $\mathrm{pH}$ on nisin $\mathrm{Z}$ activity The $\mathrm{pH}$ of the active fraction $(\mathrm{pH}$ 3.6) obtained from cation-exchange chromatography was adjusted with $\mathrm{NaOH}$ or $\mathrm{HCl}$ to the following $\mathrm{pHs:}$ 3.6, 5.0, 7.0 and 9.0. The samples at each $\mathrm{pH}$ were autoclaved at $110^{\circ} \mathrm{C}$ for $10 \mathrm{~min}$ or allowed to stand at $4^{\circ} \mathrm{C}$ overnight. Thereafter, the samples were adjusted to $\mathrm{pH} 3.6$ again and then assayed for antimicrobial activity against the indicator strain.

Sensitivity of nisin variants to proteolytic enzymes A $0.2 \mathrm{mg} / \mathrm{ml}$ sample of the purified peptides (nisin $\mathrm{Z}$ and nisin A) after lyophilization was treated with various proteolytic enzymes at a final concentration of $1 \mathrm{mg} / \mathrm{ml}$. The following enzymes were dissolved in $50 \mathrm{mM}$ potassium phosphate buffer at the respective pHs: $\alpha$-chymotrypsin (Sigma Chemical Company, St. Louis, Mo.), pH 7.5; trypsin (Sigma), pH 7.5; papain (Wako Pure Chemical Industries, Ltd., Osaka), pH 6.0; proteinase K (Merck, Darmstadt, Germany), $\mathrm{pH} 7.5$; ficin (Sigma), pH 7.0; pancreatin (Nacalai Tesque, Inc., Kyoto), pH 7.5; actinase E (Kakenseiyaku, Tokyo), pH 7.5. Pepsin (Nacalai Tesque) was dissolved in $0.01 \mathrm{~N} \mathrm{HCl}(\mathrm{pH} \mathrm{1.8).} \mathrm{The}$ reaction mixtures (total volume of $2 \mathrm{ml}$ ) were incubated at the following temperatures: $\alpha$-chymotrypsin, trypsin and papain at $25^{\circ} \mathrm{C}$; pepsin, proteinase $\mathrm{K}$ and ficin at $37^{\circ} \mathrm{C}$; pancreatin and actinase $\mathrm{E}$ at $40^{\circ} \mathrm{C}$. After incubation for $24 \mathrm{~h}$, the $\mathrm{pHs}$ of the reaction mixtures were adjusted to $\mathrm{pH} 3$ with $\mathrm{HCl}$ or $\mathrm{NaOH}$. Thereafter, the reaction mixtures were autoclaved at $110^{\circ} \mathrm{C}$ for $10 \mathrm{~min}$ to inactivate their enzymes. Subsequently, the antimicrobial activities of the reaction mixtures were determined by bioassay and expressed as relative values. The activities of each nisin variant after $24 \mathrm{~h}$ of incubation in each reaction solution without any enzymes were expressed as $100 \%$. The tests of enzyme sensitivity were performed in triplicate.

Antimicrobial action Exponential growth phase cells of $B$. subtilis $\mathrm{Cl}$ (indicator strain) were prepared by incubation at $30^{\circ} \mathrm{C}$ for $3 \mathrm{~h}$ aerobically in 500-ml shaking flasks with a working volume of $100 \mathrm{ml}$ of the assay medium. Five milliliters of nisin $\mathrm{Z}$ purified from strain IO-1 $(3 \mathrm{mg} / \mathrm{ml}$ in $0.02 \mathrm{~N} \mathrm{HCl}$ containing $0.75 \% \mathrm{NaCl}$ ) were aseptically added to the culture, and the flask was then subjected to the subsequent incubation. Hydrochloric acid solution $(0.02 \mathrm{~N}, 0.75 \% \mathrm{NaCl})$ was added to the culture as a control. Cell growths were confirmed by measurement of the absorbance at $562 \mathrm{~nm}$.

Antimicrobial spectra of nisin variants The antimicrobial spectra of nisin $\mathrm{Z}$ and nisin A purified from strain IO-1 and strain NCDO 497 were obtained according to the method described previously (Matsusaki et al., 1996a). The minimum inhibitory concentrations (MICs) of nisin variants 
were taken as the minimum effective activity of the nisin variants per milliliter of the assay medium.

\section{Results and Discussion}

$p H$ and heat stability of nisin $Z$ When autoclaved at $110^{\circ} \mathrm{C}$ and $\mathrm{pH} 3.6$ for $10 \mathrm{~min}$, nisin $\mathrm{Z}$ was not inactivated as shown in Fig. 2. On the other hand, $60 \%$ and more than $85 \%$ of the activity were lost by the same treatment at $\mathrm{pH} 5.0$ and above $\mathrm{pH} 7.0$, respectively. The storage at $4^{\circ} \mathrm{C}$ overnight resulted in good stability in the acidic $\mathrm{pH}$ range but partially inactivated nisin $\mathrm{Z}$ in the neutral and alkaline $\mathrm{pH}$ range. These characteristics were similar to those of nisin A (Hurst, 1981).

Effect of proteolytic enzymes on antimicrobial activity No activity of nisin $\mathrm{Z}$ was detected in the range of the concentration examined by treatment with proteinase $K$ and actinase $\mathrm{E}$ (Table 1), and the peak of original nisin $\mathrm{Z}$ determined by HPLC disappeared after the treatment (data not shown). This means that nisin $\mathrm{Z}$ is completely degraded and inactivated by treatment with proteinase $K$ and actinase E. The activity of nisin $\mathrm{Z}$ was decreased by treatment with $\alpha$-chymotrypsin, trypsin, papain, ficin and pancreatin, which still remained. Although the peak of the original nisin $\mathrm{Z}$ was not detected by HPLC after the treatments (data not shown), the enzymatic digests of nisin $\mathrm{Z}$ still had a low antimicrobial activity. Actually, it has been reported that the minimum structure of nisin $\mathrm{A}$ for antimicrobial activity is nisin $\mathrm{A}^{1-19}$ (Wakamiya et al, 1991). Therefore, the enzymatic digests seem to retain the structure exhibiting antimicrobial activities. Pepsin was shown to be ineffective on the activity of nisin $\mathrm{Z}$. These results nearly corresponded to those of nisin A purified from strain NCDO 497 (Table 1).

It has been known that nisin $\mathrm{A}$ is inactivated by treatment with $\alpha$-chymotrypsin and pancreatin (Jarvis \& Mahoney, 1969; Hurst, 1981). Jarvis and Mahoney (1969) also showed that the nisin-inactivating component of pancreatin was

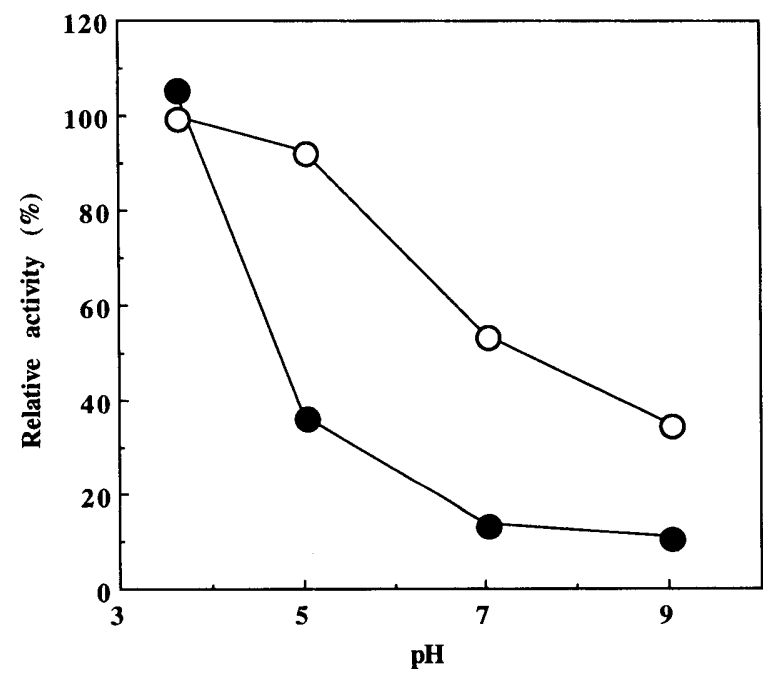

Fig. 2. $\mathrm{pH}$ and heat stability of nisin $\mathrm{Z}$. Nisin $\mathrm{Z}$ was autoclaved at $110^{\circ} \mathrm{C}$ for $10 \mathrm{~min}(\bullet)$ or allowed to stand at $4^{\circ} \mathrm{C}$ overnight $(O)$. The activities after the treament are shown as relative values. The activity of nisin $\mathrm{Z}$ stored at $\mathrm{pH} 3.6$ overnight is expressed as $100 \%$. $\alpha$-chymotrypsin. However, both nisin variants were not inactivated completely by $\alpha$-chymotrypsin although the activities decreased (Table 1). The enzyme cleaves the peptide bond between residues 31 and 32 (His-Val) of nisin A (Hurst, 1981). Therefore, nisin $A^{1-31}$ formed by the treatment of $\alpha$-chymotrypsin should have moderate antimicrobial activity because the enzyme-digested nisin has the minimum structure for antimicrobial activity in a manner similar to that described above. On the other hand, pepsin and trypsin were reported to be without effect on nisin A activity (Jarvis \& Mahoney, 1969). In this study, trypsin allowed both nisin $Z$ and nisin A to decrease in activity, the trypsin-digests having still less antimicrobial activity as in the case of $\alpha$-chymotrypsin.

The alteration in activities of the two nisin variants after proteolytic enzymes treatment provided different results in this study from those hitherto reported. The differences might be due to the sensitivity of the bioassay. The sensitivity of the bioassay is most important for the alteration in antimicrobial activity. Critical dilution assay (Mayr-Harting et al., 1972) is generally used in which the activity is defined as the reciprocal of the highest dilution yielding a clear zone of growth inhibition on the indicator lawn (agar plate assay), always under carefully standardized conditions. Nisin is regarded as difficult to diffuse in agar because of its hydrophobic property; therefore, the diffusion would be different in the enzyme-digested nisin and the agar diffusion assay may lead to erroneous results in this investigation. Therefore, turbidimetry is available for the determination of the activity compared with the agar diffusion assay. Additionally, a poor assay medium was used in this study, resulting in high sensitivity in the bioassay for detecting subtle activity of the enzyme-digested nisin. Secondly, some papers described the effect of proteolytic enzymes on nisin activity using crude nisin such as the culture supernatant and commercial nisin whose content is only 2.5\% (Jarvis 1967; Jarvis \& Mahoney, 1969). Impurities in the samples might interfere with the accurate analysis. Here, pure nisin $\mathrm{Z}$ and nisin $\mathrm{A}$ were used to investigate the effect of proteolytic enzymes on the activities of the two nisin variants. Consequently, we elucidated that both nisin variants were inactivated or affected in activity by the treatment not only with $\alpha$-chymotrypsin but also with other proteolytic enzymes in a similar manner, although the structures are slightly different. Thus far it has been reported

Table 1. Effect of proteolytic enzymes on the antimicrobial activity.

\begin{tabular}{lcc}
\hline \multirow{2}{*}{ Enzyme } & \multicolumn{2}{c}{ Relative activity (\%) } \\
\cline { 2 - 3 } & Nisin Z & Nisin A \\
\hline Controls $^{a)}$ & 100 & 100 \\
Pepsin & 100 & 100 \\
$\alpha_{\text {-Chymotrypsin }}$ & 22 & 23 \\
Trypsin & 23 & 23 \\
Papain & 31 & 57 \\
Proteinase K & $<10$ & $<10$ \\
Ficin & 35 & 55 \\
Pancreatin & 21 & 34 \\
Actinase E & $<5$ & $<5$ \\
\hline
\end{tabular}

a) The activities of nisin variants after $24 \mathrm{~h}$ of incubation in each reaction solution without any enzymes are expressed as $100 \%$. 
that the activity of nisin A is affected only by $\alpha$-chymotrypsin.

Antimicrobial action The effect of nisin $\mathrm{Z}$ on a sensitive indicator was examined to establish whether it demonstrated a bactericidal or a bacteriostatic mode of action. When nisin $\mathrm{Z}$ was added to exponential growth culture of the indicator strain, the absorbance value at $562 \mathrm{~nm}$ decreased rapidly (Fig. 3). This was due to cell lysis of the indicator strain, which was microscopically confirmed. Thus, nisin $\mathrm{Z}$ exhibited a bactericidal mode of action against the indicator, B. subtilis $\mathrm{C} 1$.

Antimicrobial spectrum Nisin $\mathrm{Z}$ as well as nisin A inhibited the cell growths of various Gram-positive bacteria (Table 2). The MICs of nisin Z were almost the same as those of nisin A. The sensitivities of each test strain toward nisin differed from the others in this study and our previous paper (Matsusaki et al, 1996a). This is probably due to the impurities in the nisin samples as described above.

Bacteriocin-producing strains were generally immune to their own products and also showed similar immunity to the analogous antibiotics, indicating cross-immunity (De Vuyst \& Vandamme, 1994). However, the cell growths of strains IO-1 and NCDO 497 were not observed by the addition of nisin variants under the assay conditions as described in the Materials and Methods section. The MICs of nisin $\mathrm{Z}$ against strains IO-1 and NCDO 497 were 200 and $150 \mathrm{AU} / \mathrm{ml}$, respectively, as in the case of nisin A (Table 2). Although nisin-producing strains have the immunity gene, nisI (Kuipers et al., 1993; Engelke et al, 1994; Siegers \& Entian, 1995), it was found that the growths of these strains were inhibited by the high concentration of nisin in this study. It has been reported that the bactericidal action of nisin A occurs in the cytoplasmic membrane of an indicator cell (Henning et al, 1986; Sahl, 1991). Cellular damage ranges from the loss of the proton motive force to the disruption of the cellular integrity of the membrane. The growth inhibition of nisin-producing strains by a high concentration of nisin may be due to the

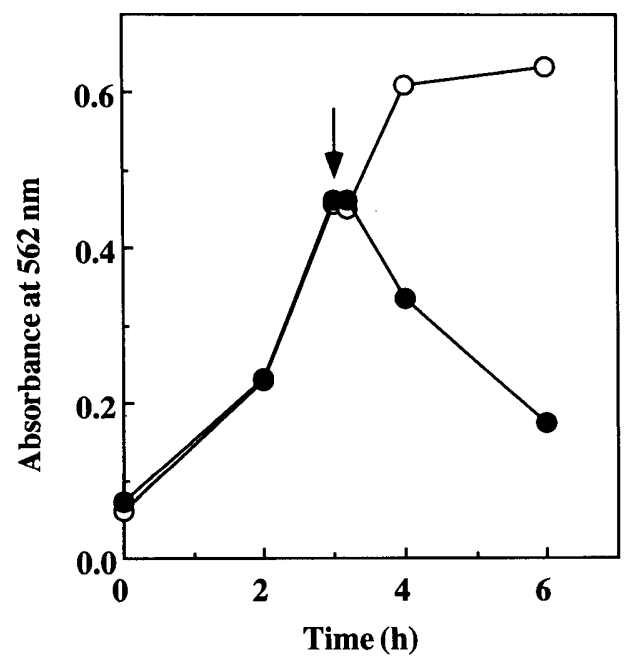

Fig. 3. Bactericidal activity of nisin $\mathrm{Z}$ against $B$. subtilis $\mathrm{C} 1$. The growth of $B$. subtilis $\mathrm{Cl}$ was followed by measuring the absorbance at $562 \mathrm{~nm}$. Arrow indicates the time of addition of nisin $\mathrm{Z}$ :, addition of nisin $\mathrm{Z} ; \bigcirc$, control (without nisin Z). long lag time necessary for the expression of the nisI gene, or the repair of the pores of the cytoplasmic membrane caused by nisin.

Nisin production was shown to be growth-associated for most of the growth of the producing-strains (De Vuyst \& Vandamme, 1992; Matsusaki et al., 1996b). The above-mentioned phenomena such as bacteriostatic action probably result from product inhibition. Therefore, it is preferable to remove the nisin $\mathrm{Z}$ produced from the culture broth when the effective continuous production of nisin $\mathrm{Z}$ is carried out. Construction of an integrated bioreactor system with a nisin $\mathrm{Z}$ separation unit is now in progress.

Furthermore, E. coli, a Gram-negative bacterium, was also inhibited by nisin variants at a concentration of $300 \mathrm{AU} / \mathrm{ml}$. In Gram-negative bacteria, the outer membrane of the envelope probably acts as a permeability barrier for the cells Growth inhibition of Gram-negative bacterium, Salmonella typhimurium against nisin A using chelating agent EDTA was also reported (Stevens et al., 1991), although Gram-negative bacteria were generally resistant to nisin A. EDTA binds magnesium ions in the lipopolysaccharide layer, resulting in an increase in susceptibility to antibiotics. As described above, Gram-negative bacteria are resistant to nisin, although the cell growth of $E$. coli was slightly affected by the nisin variants in this study (Table 2). Using a high concentration of nisin, Henning et al. (1986) noted the inhibition of yeasts and only a few species of fungi.

After subsequent cultivation for $48 \mathrm{~h}$, the nisin-producing strains and E. coli gradually grew and reached the same level as the controls (without the nisin variants). Therefore, this may not be a killing effect like the bactericidal action observed in Fig. 3 but is probably due to bacteriostatic action. Nisin $\mathrm{Z}$ inactivated by autoclaving at $\mathrm{pH} 12$ did not inhibit the cell growths of nisin-producing strains and $E$. coli (data not shown); therefore, it was clearly regarded that the active nisin $\mathrm{Z}$ provided the inhibitory function.

In this study, we investigated some characteristics of nisin

Table 2. Antimicrobial spectra of the purified nisin variants.

\begin{tabular}{lcc}
\hline & \multicolumn{2}{c}{ Minimum inhibitory concentration (MIC) } \\
\cline { 2 - 3 } Strains & $\begin{array}{c}\text { Nisin Z from strain } \\
\text { IO-I (AU/ml) }\end{array}$ & $\begin{array}{c}\text { Nisin A from strain } \\
\text { NCDO 497 (AU/ml) }\end{array}$ \\
\hline B. subtilis C1 & 10 & 10 \\
B. subtilis JCM 1465 & 20 & 20 \\
B. coagulans JCM 2257 & 10 & 5 \\
B. stearothermophilus JCM $2501^{\mathrm{T}}$ & 2.5 & 2.5 \\
M. luteus IFO 12708 & 5 & 5 \\
E. faecalis JCM 5803 & 40 & 50 \\
Cl. acetobutylicum IFO 13948 $^{\mathrm{T}}$ & 2 & 1 \\
L. lactis subsp. cremoris TUA 1344L & 10 & 10 \\
L. lactis subsp. lactis JCM 5805 & 20 & 20 \\
L. lactis NCDO 497 & 150 & 150 \\
L. lactis IO-1 & 200 & 200 \\
E. coli JM 109 & 300 & 300 \\
\hline
\end{tabular}

Nisin Z and A purified from $L$. lactis IO-1 and NCDO 497, respectively, were used in this experiment. All the assay media were 10-fold diluted compared to the usual ones as described previously (Matsusaki et al., 1996a). JCM, Japan Collection of Microorganisms; IFO, Institute for Fermentation, Osaka, Japan; TUA, Tokyo University of Agriculture, Japan; NCDO, National Collection of Dairy Organisms, Reading, England. 
Z, a natural nisin variant, produced by $L$. lactis IO-1. As a consequence, the characteristics of the peptide were almost the same as those of nisin A. We found that the more effective proteolytic enzymes (proteinase $\mathrm{K}$ and actinase $\mathrm{E}$ ) rather than $\alpha$-chymotrypsin hitherto reported inactivated the nisin variants and elucidated that $\alpha$-chymotrypsin could not completely inactivate the nisin variants although it caused a decrease in the activity. Furthermore, nisin variants inhibited not only the growths of Gram-positive bacteria but also the growths of $E$. coli, a Gram-negative bacterium, and nisinproducing strains. When a fine change in bacteriocin activity is investigated, an assay method for accurate evaluation should be the most important and must be introduced. Here, an assay medium consisting of poor nutrients was used to increase detectable sensitivity, while a nutrient-rich medium requires a large amount of the purified antibiotic due to the higher growth rate of an indicator strain, and the antimicrobial activity of the enzyme-digested antibiotic cannot be detected. The poor assay medium contributed to the effective bioassay, resulting in the findings obtained in this study. The results described here will lead to further study on nisin, for example, the development of a bioreactor with a separation system to avoid product (nisin) inhibition for enhancement of nisin productivity and downstream processing such as the fractionation and the extraction of nisin. The stability of nisin is related to its solubility (De Vuyst \& Vandamme, 1994). If nisin is more soluble and stable at neutral $\mathrm{pH}$, it would be widely applicable as a food preservative. It is expected that nisin $\mathrm{Z}$ should be more soluble than nisin $\mathrm{A}$ above $\mathrm{pH} 6$ because the asparagine side chain is more polar than the histidine side chain. Therefore, nisin $\mathrm{Z}$ should be used rather than nisin $A$ as a food preservative. However, the property of nisin $\mathrm{Z}$ is not necessarily superior to that of nisin A because nisin $\mathrm{Z}$ is also unstable above $\mathrm{pH} 7$ (Fig. 2). That is, even natural nisin $\mathrm{Z}$, which differs from nisin $\mathrm{A}$ by only a single substituted amino acid residue, is insufficient for use at neutral $\mathrm{pH}$. The stability of nisin $\mathrm{Z}$ should be improved by protein engineering, and the biological and chemical properties of the engineered mutants have to be evaluated in comparison with the wild-type nisin $Z$. The results of wild-type nisin $Z$ obtained in this study will contribute to create a more stable nisin $\mathrm{Z}$ mutant with functional properties. Because the minimum structure for antimicrobial activity is nisin ${ }^{1-19}$ (Wakamiya et al., 1991), the C-terminal amino acid residue should be substituted by a polar amino acid using a method such as site-directed mutagenesis. If the nisin $\mathrm{Z}$ mutant with high stability and antimicrobial activity at neutral $\mathrm{pH}$ is constructed and its safety is recognized, the use of the mutant could be widespread not only as a food preservative but also as an antibiotic agent.

\section{References}

Delves-Broughton, J. (1990). Nisin and its use as a food preservative. Food Technol, 44, 100-117.

De Vuyst, L. and Vandamme, E.J. (1992). Influence of the carbon source on nisin production in Lactococcus lactis subsp. lactis batch fermentations. J. Gen. Microbiol., 138, 571-578.

De Vuyst, L. and Vandamme, E.J. (1994). "Bacteriocins of Lactic Acid Bacteria." Blackie Academic \& Professional, Glasgow.

Engelke, G., Gutowski-Eckel, Z., Kiesau, P., Siegers, K., Hammelmann, M. and Entian, K.-D. (1994). Regulation of nisin biosynthesis and immunity in Lactococcus lactis 6F3. Appl. Environ. Microbiol., 60, 814-825

Gross, E. and Morell, J.L. (1971). The structure of nisin. J. Am. Chem. Soc., 93, 4634-4635.

Henning, S., Metz, R. and Hammes, W.P. (1986). Studies of the mode of action of nisin. Int. J. Food Microbiol, 3, 121-134.

Hurst, A. (1981). Nisin. Adv. Appl. Microbiol, 27, 85-123.

Jarvis, B. (1967). Resistance to nisin and production of nisin-inactivating enzymes by several Bacillus species. J. Gen. Microbiol., 47, 33-48.

Jarvis, B. and Mahoney, R.R. (1969). Inactivation of nisin by alphachymotrypsin. J. Dairy Sci., 52, 1448-1450.

Klaenhammer, T.R. (1988). Bacteriocins of lactic acid bacteria. Biochimie, 70, 337-349.

Klaenhammer, T.R. (1993). Genetics of bacteriocins produced by lactic acid bacteria. FEMS Microbiol. Rev., 12, 39-86.

Kuipers, O.P., Beerthuyzen, M.M., Siezen, R.J. and de Vos, W.M. (1993). Characterization of the nisin gene cluster nisABTCIPR of Lactococcus lactis. Requirement of expression of the nis $A$ and nisI genes for development of immunity. Eur. J. Biochem., 216, 281-291.

Matsusaki, H., Endo, N., Sonomoto, K. and Ishizaki, A. (1996a). Development of purification method of a peptide antibiotic produced by Lactococcus lactis IO-1. Food Sci. Technol., Int, 2, 157162.

Matsusaki, H., Endo, N., Sonomoto, K. and Ishizaki, A. (1996b). Lantibiotic nisin $\mathrm{Z}$ fermentative production by Lactococcus lactis IO-1: Relationship between production of the lantibiotic and lactate and cell growth. Appl. Microbiol. Biotechnol., 45, 36-40.

Mayr-Harting, A., Hedges, A.J. and Berkeley, R.C.W. (1972). Method for studying bacteriocins. Methods Microbiol., 7A, 315-422.

Mulders, J.W.M., Boerrigter, I.J., Rollema, H.S., Siezen, R.J. and de Vos, W.M. (1991). Identification and characterization of the lantibiotic nisin Z, a natural nisin variant. Eur. J. Biochem., 201, 581 584.

Nettles, C.G. and Barefoot, S.F. (1993). Biochemical and genetic characteristics of bacteriocins of food-associated lactic acid bacteria. J. Food Prot., 56, 338-356.

Ralph, W.J., Tagg, J.R. and Ray, B. (1995). Bacteriocins of Grampositive bacteria. Microbiol. Rev., 59, 171-200.

Sahl, H.-G. (1991). Pore formation in bacterial membranes by cationic lantibiotics. In "Nisin and Novel Lantibiotics," ed. by G. Jung and H.-G. Sahl. ESCOM Science Publishers B.V., Leiden, pp. 347-358.

Siegers, K. and Entian, K.-D. (1995). Genes involved in immunity to the lantibiotic nisin produced by Lactococcus lactis 6F3. Appl. Environ. Microbiol., 61, 1082-1089.

Stevens, K.A., Klapes, N.A., Scheldon, B.W. and Klaenhammer, T.R. (1991). Nisin treatment for inactivation of Salmonella species and other Gram-negative bacteria. Appl. Environ. Microbiol., 57, 36133615

Wakamiya, T., Fukase, K., Sano, A., Shimbo, K., Kitazawa, M., Horimoto, S., Fujita, H., Kubo, A., Maeshiro, Y. and Shiba, T. (1991). Studies on chemical synthesis of the lanthionine peptide nisin. In "Nisin and Novel Lantibiotics," ed. by G. Jung and H.-G. Sahl. ESCOM Science Publishers B.V., Leiden, pp. 189-203. 